\title{
INVENTARISASI HAMA AKIBAT PERLAKUAN MACAM PUPUK KANDANG TERHADAP TIGA JENIS PADI (Oryza sativa L. )
}

\author{
M Syamsul Hadi ${ }^{*}$ Sartono Joko $^{1}$ Siswadi $^{1}$ \\ ${ }^{1}$ Program Studi Agroteknologi Fakultas Pertanian Universitas Slamet Riyadi surakarta \\ 1*syamchul27@gmail.com
}

\begin{abstract}
ABSTRAK
Tujuan penelitian ini untuk mengetahui jenis-jenis hama dari gejala dan tanda kerusakan dari perlakuan macam pupuk kandang terhadap tiga jenis padi. Penelitian ini telah dilaksanakan pada bulan Oktober 2018 sampai dengan bulan Januari 2019, tempat penelitian di Dusun Brongsongan, Desa Sidorejo, Kecamatan Bendosari, Kabupaten Sukoharjo dengan jenis tanah Grumusol dan ketinggian tempat \pm 125 meter dpl. Penelitian ini menggunakan Rancangan Acak Kelompok Lengkap (RAKL) yang di susun secara Split Plot terdiri dari 2 faktor perlakuan yaitu macam jenis padi ( V ) sebagai main plot ( petak utama) dan pupuk kandang ( P ) sebagai sub plot ( anak petak ), sehingga diperoleh 12 kombinasi perlakuan dan masing-masing diulang 3 kali. Hasil penelitian menunjukkan ( 1 ) Jenis hama yang di temukan pada saat penelitian yaitu hama belalang hijau dengan intensitas serangan tertinggi pada perlakuan jenis padi hitam dan pupuk kandang kambing ( V1P2 ) yaitu rata-rata $27.12 \%$, hama penggerek batang putih dengan intensitas serangan tertinggi pada perlakuan jenis padi merah dan tanpa pupuk ( V2P0 ) yaitu rata-rata $26.85 \%$, hama burung bondol jawa dengan intensitas serangan tertinggi pada perlakuan jenis padi merah dan perlakuan pupuk kandang kambing ( V2P2 ) yaitu rata-rata 32.63\%, dan hama tikus sawah dengan intensitas serangan tertinggi pada semua perlakuan jenis padi putih dan pemberian macam pupuk kandang yaitu rata-rata $90.00 \%$. ( 2 ) Pemberian pupuk kandang ayam tidak berpengaruh nyata terhadap intensitas serangan hama terhadap tiga jenis padi. ( 3 ) Jenis padi merah dan perlakuan pupuk kandang kambing ( V2P2 ) memiliki hasil tertinggi untuk berat kering panen dan berat kering giling yaitu rata-rata $421.21 \mathrm{gram} / \mathrm{m}^{2}$ dan $283.70 \mathrm{gram} / \mathrm{m}^{2}$, serta untuk berat 100 biji yang tertinggi pada perlakuan jenis padi merah dan perlakuan pupuk kandang sapi ( V2P1 ) yaitu rata-rata $2.64 \mathrm{gram} / \mathrm{m}^{2}$.
\end{abstract}

Keyword : Hama, Padi dan Pupuk Kandang.

\section{ABSTRACT}

The purpose of this study was to determine the types of pests from the symptoms and signs of damage from various types of manure treatment on three types of rice. This research was conducted in October 2018 until January 2019, a research site in Brongsongan Hamlet, Sidorejo Village, Bendosari Subdistrict, Sukoharjo Regency with Grumusol soil types and altitude \pm 125 meters above sea level. This study uses a Complete Randomized Block Design $(R A K L)$ arranged in Split Plots consisting of 2 treatment factors, namely the type of rice $(V)$ as the main plot (main plot) and manure $(P)$ as a sub plot (subplot), so 12 treatment combinations were obtained and each was repeated 3 times. The results showed (1) The types of pests found at the time of the study were green grasshopper pests with the highest attack intensity in the treatment of black rice and goat manure (VIP2), which was an average of $27.12 \%$, white stem borer with the highest intensity of attack Red rice and without fertilizer (V2P0) were $26.85 \%$ on average, Java bondol bird pest intensity with attack intensity was in the treatment of red rice species and the treatment of goat manure (V2P2) was $32.63 \%$ on average, and the rice field rat pest with the highest attack intensity was all the treatment of the type of white rice and the administration of various types of manure is an average of 90.00\%. (2) The provision of chicken manure does not significantly affect the intensity of pest attacks on three types of rice. (3) Red rice type and goat manure treatment (V2P2) had the highest yield for harvest dry weight and milled dry weight, which was an average of $421.21 \mathrm{gram} / \mathrm{m}^{2}$ and $283.70 \mathrm{gram} / \mathrm{m}^{2}$, and for the 
highest weight of 100 seeds in rice type treatment red and cow manure treatment (V2P1) which is an average of $2.64 \mathrm{gram} / \mathrm{m}^{2}$.

Keyword: Pests, Rice and Manure.

\section{PENDAHULUAN}

Tanaman padi ( Oryza sativa L. )
merupakan bahan makanan yang mengandung gizi dan penguat yang cukup bagi tubuh manusia. Dalam usaha mempertahankan kelangsungan hidup, manusai memenuhi kebutuhan pokonya, dan salah satu kebutuhan pokok itu adalah makanan ( Anonim, 1990 ). Menurut Badan Pusat Statistik ( BPS 2008 ) masyarakat Indonesia mengkonsumsi beras mencapai $139 \mathrm{~kg}$ per kapita per tahun.

Jenis beras dapat dibagi menjadi beras putih, beras merah, dan beras hitam (Anonim, 2004). Beras merah dan hitam merupakan bahan pangan yang potensial untuk progam diversifikasi pangan. Hal ini dikarenakan kandungan gizi dari beras merah dan hitam lebih tinggi dibandingkan dengan beras putih yang biasa dikonsumsi oleh sebagian besar penduduk di Indonesia.

Pupuk kandang adalah pupuk yang berasal dari kotoran ternak atau hewan dan urin, serta sisa-sisa makanan yang tidak dapat dihabiskan. Pupuk kandang mempunyai sifat yang lebih baik dari pupuk alam lainnya maupun pupuk buatan, yaitu : merupakan humus atau zat-zat organik yang terdapat di dalam tanah yang terjadi karena proses pemecahan sisa-sisa tanaman dan hewan. Pupuk kandang merupakan sumber hara nitrogen, fosfor, dan kalium yang amat penting bagi pertumbuhan dan perkembangan tanaman. Pupuk kandang juga dapat meningkatkan daya menahan air dan juga banyak mengandung mikroorganisme yang dapat menghancurkan sampah-sampah yang ada di dalam tanah sehingga berubah menjadi humus ( Soepardi, 1983 ).

Hama tanaman padi menjadi hal penting yang selalu saja dibicarakan dalam budidaya pertanian, termasuk pertanian padi sawah. Hal ini karena hama dianggap sebagai musuh petani dalam memperoleh produksi padi. Tanaman padi yang sehat yaitu tanaman yang tidak terserang oleh hama dan penyakit, tetapi yang terjadi tanaman padi juga tidak luput dari gangguan hama dan penyakit ( Sembiring, 2013 ). Sebagian besar hama adalah jenis serangga (Channa, Bambadeniya dan Felix, 2004), dan berbagai jenis serangga hama tersebut mempunyai musuh alami (natural enemy). Jenis hewan yang paling banyak menyerang ialah serangga.

Penelitian ini bertujuan untuk mengetahui jenis-jenis hama dari gejala dan tanda kerusakan dari perlakuan macam pupuk kandang terhadap tiga jenis padi. Di duga dengan pemberian pupuk kandang ayam terhadap tiga jenis padi dapat memacu intensitas serangan hama.

\section{METODE PENELITIAN \\ Rancangan Penelitian}

Dalam penelitian ini menggunakan Rancangan Acak Kelompok Lengkap (RAKL) yang di susun secara Split Plot terdiri dari 2 faktor perlakuan yaitu macam jenis padi sebagai main plot ( petak utama) dan pupuk kandang sebagai sub plot ( anak petak ), sehingga diperoleh 12 kombinasi perlakuan dan masing-masing perlakuan diulang sebanyak 3 kali.

\section{Bahan dan Alat}

1. Bahan

Bahan yang digunakan yaitu : benih padi hitam ( varietas cempo ireng ), benih padi merah ( varietas cempo abang ) dan benih padi putih (varietas mentik susu ). Pupuk yang di gunakan yaitu : pupuk Urea, SP36, dan KCL sesuai kebutuhan. Sedangkan pupuk kandang berupa pupuk kandang sapi, kambing dan ayam.

2. Alat Penelitian

Alat yang digunakan yaitu : gelas ukur, camera, cangkul, alat pemotong atau sabit, gembor, benang, penggaris, alat tulis, kertas nama, timbangan dan oven.

\section{Pelaksanaan Penelitian}

Waktu dan Tempat Penelitian

Penelitian ini telah dilaksanakan pada bulan Oktober 2018 sampai dengan bulan Januari 2019, tempat penelitian di Dusun Brongsongan, Desa Sidorejo, Kecamatan Bendosari, Kabupaten Sukoharjo 
dengan jenis tanah Grumusol dan ketinggian tempat \pm 125 meter dpl.

\section{Pengamatan}

Pengambilan data sejak tanaman berumur 30 hari setelah tanam dengan cara mengamati setiap dua minggu sekali. Pengamatan dilakukan pada 5 tanaman sampel yang di ambil secara diagonal dari 25 tanaman di setiap petaknya dengan parameter sebagai berikut:

1. Jenis hama yang menyerang

Mengamati jenis hama apa saja yang muncul di setiap pengamatan dengan cara megambil gambar hama jika ada atau menganalisis serangan hama yang di timbulkan dari gejala dan tanda kerusakan.

2. Intensitas kerusakan

Peng-hitungan tingkat kerusakan tanaman dilakukan menurut kriteria Unterstenhofer (1963) hama sesuai tingkat serangan dengan rumus sebagai berikut :

$\mathrm{I}=\frac{\sum\left(n_{i} \times v_{i}\right)}{z x N} \times 100 \%$

Keterangan :

I = intensitas kerusakan

$\mathrm{n}_{\mathrm{i}} \quad=$ jumlah tanaman yang terserang

$\mathrm{v}_{\mathrm{i}} \quad=$ nilai klasifikasi kerusakan

$\mathrm{z}=$ nilai klasifikasi kerusakan tertinggi

$\mathrm{N} \quad=$ jumlah seluruh tanaman yang diamati

Dengan klasifikasi tingkat kerusakan sebagai berikut :

$\left.\begin{array}{llc}\hline \begin{array}{c}\text { Tingkat } \\ \text { kerusakan }\end{array} & \begin{array}{l}\text { Presentasi } \\ \text { kerusakan pada } \\ \text { tanaman }\end{array} & \begin{array}{c}\text { Klasifikasi } \\ \text { kerusakan }\end{array} \\ \hline \text { Sehat } & \begin{array}{l}\text { Tidak ada gejala } \\ \text { serangan } \\ \text { Kerusakan } \\ \text { antara 1 \% - 25 } \\ \text { Ringan }\end{array} & 0 \\ & \begin{array}{l}\text { Kerusakan } \\ \text { antara 26 \% - 50 } \\ \text { Agak berat }\end{array} & 2 \\ \text { Kerusakan } \\ \text { antara 51 \% - 75 } \\ \%\end{array}\right)$

3. Berat kering panen (gram)

Ditimbang pada saat akhir penelitian dengan cara merontokkan gabah per petak yang masih basah kemudian ditimbang dalam keadaan masih segar.

4. Berat kering giling (gram)

Berat gabah kering diamati dengan cara menimbang gabah per petaknya yang sudah dikeringkan dengan sinar matahari atau dikeringkan dengan oven pada suhu \pm $60-70^{\circ} \mathrm{C}$ selama 24 jam, sampai dengan kadar air gabar $14 \%$ agar gabah dapat di simpan tahan lama serta biji beras tidak mudah patah saat penggilingan.

5. Berat 100 biji gabah (gram)

Pengamatan dilakukan dengan cara merontokkan biji gabah kemudian di lakukan penghitungan sebanyak 100 biji di setiap petaknya, selanjutnya lakukan penimbangan 100 biji gabah yang sudah diambil pada setiap petaknya.

\section{Analisis Data}

Analisis data menggunakan Uji Beda Nyata Terkecil ( BNT ) pada taraf 5\% untuk mengetahui perlakuan-perlakuan yang berpengaruh dan yang tidak berpengaruh.

\section{HASIL DAN PEMBAHASAN Macam Hama}

Hasil pengamatan yang telah di lakukan selama 10 minggu dengan intensitas pengamatan 2 minggu sekali di lahan, ada beberapa jenis hama yang menyerang tanaman padi antara lain hama belalang, penggerek batang, burung dan hama tikus.

Tabel 1. Macam hama

\begin{tabular}{|c|c|c|c|}
\hline $\begin{array}{l}\text { Macam } \\
\text { Hama }\end{array}$ & $\begin{array}{l}\text { Jenis } \\
\text { Hama }\end{array}$ & Nama Latin & $\begin{array}{c}\text { Waktu } \\
\text { Serangan } \\
\text { Minggu } \\
\text { Ke }\end{array}$ \\
\hline Belalang & $\begin{array}{l}\text { Belalang } \\
\text { Hijau }\end{array}$ & Oxya chinensis & 2 \\
\hline Burung & $\begin{array}{l}\text { Burung } \\
\text { Bondol } \\
\text { Jawa }\end{array}$ & $\begin{array}{c}\text { Lonchura } \\
\text { leucogastroides }\end{array}$ & 6 \\
\hline $\begin{array}{l}\text { Penggerek } \\
\text { Batang }\end{array}$ & $\begin{array}{l}\text { Penggerek } \\
\text { Batang } \\
\text { Putih }\end{array}$ & $\begin{array}{l}\text { Tryporyza } \\
\text { innotata }\end{array}$ & 6 \\
\hline Tikus & $\begin{array}{l}\text { Tikus } \\
\text { Sawah }\end{array}$ & $\begin{array}{l}\text { Rattus-rattus } \\
\text { argentiventer }\end{array}$ & 8 \\
\hline
\end{tabular}

Keterangan : Data awal muncul serangan hama dari awal pengamatan sampai akhir pengamatan.

Data awal kemunculan hama menunjukkan serangan hama belalang terjadi pada pengamatan pertama pada minggu ke 2. Hal ini dikarenakan hama 
belalang dapat di temui dari fase vegetative sampai generative. Belalang memakan daun tanaman padi di bagian tepi daun sehingga mengurangi luas permukaan daun yang mengakibatkan daun menjadi berlubang. Gejalannya kadang-kadang sulit di bedakan dengan serangan ulat daun, lubang akibat serangan belalang tepinya bergerigi dan kasar, sedangkan hama ulat lebih halus. Meskipun kerusakan daun tidak serius akan tetapi kerusakan ini mengakibatkan pengaruh terhadap berkurangnya produktifitas tanaman padi yang terserang.

Hama burung dan penggerek batang muncul di minggu ke 6 pada pengamatan ke3. Hama burung merupakan hama yang mengakibatkan serangan ringan sampai serangan berat dan dapat mengakibatkan penurusan hasil panen maupun gagal panen. Biasanya kerugian yang di sebabkan akibat serangan hama burung bisa mencapai 1580\% ( Nutani, 2016 ). Hama burung menyerang pada vase generatife yaitu pada saat fase matang susu sampai pemasakan biji. Gejala serangan burung yaitu rusaknya malai atau berkurangnya jumlah biji pada malai akibat di makan burung. Hama burung hanya menyerang tanaman padi jenis padi merah (V2) karena jenis padi merah sudah terlebih dahulu mengeluarkan malai di bandingakan kedua jenis padi yang lain. jenis padi merah ini juga panen lebih cepat di bandingkan dari kedua jenis padi pembanding yang lain dan tidak sesuai perkiraan umur padi merah tersebut, karena seharusnya umur panen padi merah itu 110 HST sedangkan yang terjadi di lapangan umur panen padi merah hanya $80 \mathrm{HST}$.

Di Indonesia, serangan hama penggerek batang terluas setelah tikus. Dalam 10 tahun terakhir serangan hama ini di perkirakan mencapai 85.000 hektar sawah di seluruh Indonesia dengan serangan 0,5$90 \%$. Serangan bisa terjadi sejak persemaian sampai pertumbuhan dan perkembangan ( Chandra, 2014 ). Hama penggerek batang menyerang titik tumbuh tanaman padi yang di makan oleh larva penggerek batang tersebut. Gejala serangan hama ini di tandai dengan adanya daun yang menguning dan mengering di awali dari ujung daun sampai batang padi dan tanaman padi mudah di cabut. Apabila serangan terjadi pada tanaman padi yang masih muda mengakibatkan anakan yang rusak bewarna coklat dan mati, kondisi ini di sebut sundep. Jika kerusakan terjadi pada fase pembentukan malai, maka malai akan berwarna putih dan kosong yang di sebut beluk.

Serangan hama tikus menyerang pada minggu ke 8 pada jenis padi putih dan hitam pada saat generative. Gejala serangan hama ini di tandai dengan rusaknya batang akibat gigitan tikus yang mengakibatkan tanaman roboh maupun patah, tanaman akan menguning, rusak dan berantakan akibat serangan hama tersebut. Hama tikus terlebih dahulu menyerang padi putih dengan intensitas serangan yang lebih berat di bandingkan dengan padi hitam, setelah padi putih rusak baru kemudian hama tikus menyerang yang padi hitam. Perbedaan varietas ini berpengaruh terhadap serangan tikus di karenakan setiap varietas memiliki jaringan sel yang tidak sama (Salisbury dan Ross, 1995 ). Akibat serangan tikus yang sangat berat mengakibatkan padi putih dam hitam gagal panen.

\section{Intensitas Kerusakan}

Tabel 2. Intensitas kerusakan hama

\begin{tabular}{|c|c|c|c|c|}
\hline \multirow{2}{*}{$\begin{array}{c}\text { Perlak } \\
\text { uan }\end{array}$} & \multicolumn{4}{|c|}{ Macam Hama } \\
\hline & Belalang & $\begin{array}{c}\text { Penggerek } \\
\text { Batang }\end{array}$ & Burung & Tikus \\
\hline V1P0 & $24.49 \mathrm{~b}$ & $10.60 \mathrm{a}$ & 0 & $90 \mathrm{c}$ \\
\hline V1P1 & $25.92 \mathrm{~b}$ & $15.61 \mathrm{a}$ & 0 & $90 \mathrm{c}$ \\
\hline $\mathrm{V} 1 \mathrm{P} 2$ & $27.12 \mathrm{~b}$ & $10.60 \mathrm{a}$ & 0 & $90 \mathrm{c}$ \\
\hline V1P3 & $26.27 \mathrm{~b}$ & $17.36 \mathrm{~b}$ & 0 & $90 \mathrm{c}$ \\
\hline $\mathrm{V} 2 \mathrm{P} 0$ & $17.20 \mathrm{a}$ & $26.85 \mathrm{c}$ & $26.30 \mathrm{~b}$ & 0 \\
\hline $\mathrm{V} 2 \mathrm{P} 1$ & $11.84 \mathrm{a}$ & $21.09 \mathrm{c}$ & $27.87 \mathrm{~b}$ & 0 \\
\hline $\mathrm{V} 2 \mathrm{P} 2$ & $16.05 \mathrm{a}$ & $13.51 \mathrm{a}$ & $32.63 \mathrm{~b}$ & 0 \\
\hline $\mathrm{V} 2 \mathrm{P} 3$ & $16.90 \mathrm{a}$ & $17.36 \mathrm{~b}$ & $24.44 \mathrm{a}$ & 0 \\
\hline V3P0 & $16.83 \mathrm{a}$ & $10.95 \mathrm{a}$ & 0 & $84.52 \mathrm{~b}$ \\
\hline V3P1 & $23.27 \mathrm{~b}$ & $12.23 \mathrm{a}$ & 0 & $66.23 \mathrm{a}$ \\
\hline V3P2 & $24.24 \mathrm{~b}$ & $9.32 \mathrm{a}$ & 0 & $71.25 \mathrm{a}$ \\
\hline V3P3 & $23.58 \mathrm{~b}$ & $13.17 \mathrm{a}$ & 0 & $76.15 \mathrm{ab}$ \\
\hline
\end{tabular}

Keterangan : purata intensitas kerusakan hama yang diikuti huruf yang sama berarti tidak berbeda nyata pada taraf $5 \%$ uji BNT.

\section{Hama Belalang}

Hasil uji BNT pada tabel 2 pada jenis padi hitam menunjukkan bahwa pupuk kandang kambing ( V1P2) menghasilkan intensitas serangan hama belalang tertingi 
yaitu rata-rata $27.12 \%$ akan tetapi tidak berpengaruh nyata terhadap tanaman padi tanpa pupuk ( V1P0 ) yaitu rata-rata 24. $49 \%$, pupuk kandang sapi ( V1P1 ) rata-rata $25.92 \%$ dan pupuk kandang ayam ( V1P3 ) rata-rata $26.76 \%$.

Sedangkan pada jenis padi merah menunjukkan bahwa tanaman padi tanpa pupuk ( V2P0 ) menghasilkan intensitas serangan hama belalang tertingi yaitu ratarata $17.20 \%$ akan tetapi tidak berpengaruh nyata terhadap pupuk kandang sapi ( V2P1 ) yaitu rata-rata $11.84 \%$, pupuk kandang kambing ( V2P2 ) rata-rata $16.05 \%$ dan pupuk kandang ayam ( V2P3) rata-rata $16.90 \%$.

Pada jenis padi putih menunjukkan bahwa pupuk kandang kambing ( V3P2 ) menghasilkan intensitas serangan hama belalang tertingi yaitu rata-rata $24.24 \%$ akan tetapi tidak berpengaruh nyata terhadap pupuk kandang sapi ( V3P1 ) rata-rata $23.58 \%$ dan pupuk kandang ayam ( V3P3 ) rata-rata $23.27 \%$. Sedangkan berbeda nyata pada tanaman padi tanpa pupuk ( V3P0 ) yang intensitas serangan hama terendah yaitu rata-rata $16.83 \%$.

\section{Hama Pengerek Batang}

Hasil uji BNT pada tabel 2 pada jenis padi putih menunjukkan bahwa pupuk kandang ayam ( V1P3 ) menghasilkan intensitas serangan hama penggerek batang tertingi yaitu rata-rata $17.36 \%$ akan tetapi tidak berpengaruh nyata terhadap tanaman padi tanpa pupuk ( V1P0 ) yaitu rata-rata $10.60 \%$, pupuk kandang sapi ( V1P1 ) ratarata $15.61 \%$ dan pupuk kandang kambing ( V1P2 ) rata-rata $10.60 \%$.

Pada jenis padi merah menunjukkan bahwa tanaman padi tanpa pupuk ( V2P0) menghasilkan intensitas serangan hama penggerek batang tertingi yaitu rata-rata $26.85 \%$, akan tetapi tidak berpengaruh nyata terhadap pupuk kandang sapi ( V2P1 ) yaitu rata-rata $21.09 \%$, sedangkan berpengaruh nyata terhadap pupuk kandang kambing ( V2P2 ) rata-rata $17.36 \%$ dan pupuk kandang ayam ( V2P3 ) rata-rata $13.51 \%$.

Sedangkan pada jenis padi putih menunjukkan bahwa pupuk kandang kambing ( V3P2 ) menghasilkan intensitas serangan hama penggerek batang tertingi yaitu rata-rata $13.17 \%$ akan tetapi tidak berpengaruh nyata terhadap tanaman padi tanpa pupuk ( V3P0 ) yaitu rata-rata $10.95 \%$, pupuk kandang sapi ( V3P1 ) rata-rata $12.23 \%$ dan pupuk kandang ayam ( V3P3 ) rata-rata $10.60 \%$.

3. Hama Burung

Hasil uji BNT pada tabel 2 menunjukkan bahwa pupuk kandang kambing ( V2P2 ) menghasilkan intensitas serangan hama burung tertingi yaitu rata-rata $32.63 \%$ akan tetapi tidak berpengaruh nyata terhadap tanaman padi tanpa pupuk ( V2P0 ) rata-rata $26.30 \%$ dan pupuk kandang sapi ( V2P1 ) rata-rata $27.87 \%$. Sedangkan berbeda nyata pada pupuk kandang ayam ( V2P3 ) yang intensitas serangan hama burung terendah yaitu rata-rata $24.44 \%$.

4. Hama Tikus

Hasil uji BNT pada tabel 2 menunjukkan bahwa tanaman padi tanpa pupuk ( V1P0 ) menghasilkan intensitas serangan hama tikus tertingi yaitu rata-rata $84.52 \%$ akan tetapi berbeda nyata terhadap pupuk kandang sapi ( V1P1) yaitu rata-rata $66.23 \%$. Sedangkan pupuk kandang kambing ( V1P2 ) rata-rata $71.25 \%$ tidak berbeda nyata dengan pupuk kandang ayam ( V1P3 ) yang intensitas serangan hama tikus yaitu rata-rata $76.15 \%$.

Sedangkan untuk jenis padi putih menunjukkan bahwa macam pupuk kandang tidak berpengaruh nyata pada jenis padi putih terhadap intensitas serangan hama tikus di karenakan keempat macam perlakuan pupuk kandang tersebut menghasilkan rata-rata yang sama yaitu $90.00 \%$.

\section{Hasil Panen}

Tabel 3. Hasil Panen ( gram )

\begin{tabular}{|c|c|c|c|}
\hline \multirow[b]{2}{*}{$\begin{array}{l}\text { Perla } \\
\text { kuan }\end{array}$} & \multicolumn{3}{|c|}{ Macam Hama } \\
\hline & $\begin{array}{l}\text { Berat } \\
\text { Kering } \\
\text { Panen }\end{array}$ & $\begin{array}{l}\text { Berat } \\
\text { Kering } \\
\text { Giling }\end{array}$ & $\begin{array}{c}\text { Berat } \\
100 \mathrm{Biji}\end{array}$ \\
\hline V2P0 & $396.07 \mathrm{a}$ & $269.16 \mathrm{a}$ & $2.59 \mathrm{a}$ \\
\hline V2P1 & $416.91 \mathrm{~b}$ & $279.49 \mathrm{~b}$ & $2.64 \mathrm{a}$ \\
\hline $\mathrm{V} 2 \mathrm{P} 2$ & $421.21 \mathrm{~b}$ & $283.70 \mathrm{c}$ & $2.62 \mathrm{a}$ \\
\hline $\mathrm{V} 2 \mathrm{P} 3$ & $397.69 \mathrm{a}$ & $270.46 \mathrm{a}$ & $2.60 \mathrm{a}$ \\
\hline
\end{tabular}

Keterangan : purata hasil panen yang diikuti huruf yang sama berarti tidak berbeda nyata pada taraf $5 \%$ uji BNT. 


\section{Berat Kering Panen}

Hasil berat kering panen dari pengamatan intensitas serangan hama hanya terdapat pada jenis padi merah saja, dikarenakan padi hitam dan padi putih gagal panen akibat serangan hama yang berat.

Hasil uji BNT pada tabel 3 menunjukkan bahwa pupuk pupuk kandang kambing ( V2P2 ) menghasilkan berat kering panen tertingi yaitu rata-rata 421.21 $\mathrm{gram} / \mathrm{m}^{2}$, akan tetapi tidak berbeda nyata terhadap pupuk kandang sapi ( V2P1) yaitu rata-rata 416.21 gram $/ \mathrm{m}^{2}$. Sedangkan berbeda nyata dengan tanaman padi tanpa pupuk ( V2P2 ) rata-rata $396.07 \mathrm{gram} / \mathrm{m}^{2}$ dan pupuk kandang ayam ( $\mathrm{V} 2 \mathrm{P} 3$ ) yang menghasilkan berat kering panen yaitu ratarata $397.69 \mathrm{gram} / \mathrm{m}^{2}$.

2. Berat Kering Giling

Hasil uji BNT pada tabel 3 menunjukkan bahwa pupuk pupuk kandang kambing ( V2P2 ) menghasilkan berat kering giling tertingi yaitu rata-rata 283.70 $\mathrm{gram} / \mathrm{m}^{2}$, akan tetapi berbeda nyata terhadap pupuk kandang sapi ( V2P2 ) yaitu rata-rata $279.49 \mathrm{gram} / \mathrm{m}^{2}$. Sedangkan berbeda nyata dengan tanaman padi tanpa pupuk ( V2P0 ) rata-rata $269.16 \mathrm{gram} / \mathrm{m}^{2}$ dan pupuk kandang ayam ( V2P3 ) yang menghasilkan berat kering panen yaitu ratarata $270.46 \mathrm{gram} / \mathrm{m}^{2}$.

3. Berat $100 \mathrm{Biji}$

Hasil uji BNT pada tabel 3 menunjukkan bahwa pupuk pupuk kandang sapi ( V2P1 ) menghasilkan berat 100 biji tertingi yaitu rata-rata $2.64 \mathrm{gram} / \mathrm{m}^{2}$, akan tetapi tidak berbeda nyata dengan tanaman padi tanpa pupuk ( V2P0 ) rata-rata 2.59 $\mathrm{gram} / \mathrm{m}^{2}$ dan pupuk kandang kambing ( V2P2 ) rata-rata $2.62 \mathrm{gram} / \mathrm{m}^{2}$ serta pupuk kandang ayam ( V2P3) yang menghasilkan berat 100 biji yaitu rata-rata $2.60 \mathrm{gram} / \mathrm{m}^{2}$.

\section{KESIMPULAN DAN SARAN Kesimpulan}

Berdasarkan hasil penelitian dan hasil pembahasan, maka dapat di simpulkan sebagai berikut :

1. Jenis hama yang di temukan pada saat penelitian yaitu hama belalang hijau dengan intensitas serangan tertinggi pada perlakuan jenis padi hitam dan pupuk kandang sapi ( V1P1 ) dengan rata-rata
$27.12 \%$, hama penggerek batang putih dengan intensitas serangan tertinggi pada perlakuan jenis padi merah dan tanpa pupuk ( V2P0 ) dengan rata-rata $26.85 \%$, hama burung bondol jawa dengan intensitas serangan tertinggi pada perlakuan jenis padi merah dan perlakuan pupuk kandang kambing ( V2P2) dengan rata-rata $32.63 \%$, dan hama tikus sawah dengan intensitas serangan tertinggi pada semua perlakuan jenis padi putih dan pemberian macam pupuk kandang dengan rata-rata $90.00 \%$.

2. Pemberian pupuk kandang ayam tidak berpengaruh nyata terhadap intensitas serangan hama terhadap tiga jenis padi.

3. Jenis padi merah dan perlakuan pupuk kandang kambing ( V2P2 ) memiliki hasil tertinggi untuk berat kering panen dan berat kering giling dengan rata-rata $421.21 \mathrm{gram} / \mathrm{m}^{2}$ dan $283.70 \mathrm{gram} / \mathrm{m}^{2}$, serta untuk berat 100 biji yang tertinggi pada perlakuan jenis padi merah dan perlakuan pupuk kandang sapi ( V2P1 ) dengan rata-rata $2.64 \mathrm{gram} / \mathrm{m}^{2}$.

\section{Saran}

Berdasarkan hasil penelitian yang telah di laksanakan, perlu adanya penelitian lebih lanjut mengenai inventarisasi hama terhadap tiga jenis padi di lain tempat dan di lain waktu.

\section{DAFTAR PUSTAKA}

Anonim. 1990. Budidaya Tanaman Padi. Yogyakarta: Aksi Agraris Kanisius.

Anonim. 2004. Analysis of Phenolic Compounds in White Rice, Brown Rice and Germinated Brown Rice. $\mathrm{J}$ Agric Food Chem. 52 (15): 480813.

Badan Pusat Statistik (BPS) Indonesia. 2013. Produksi Padi, Jagung dan Kedelai. Jakarta: Badan Pusat Statisk.

Chandra, W. 2014. Pestisida kimia berlebihan, hama penggerek batang malah berkembang. http://www.mongabay.co.id/2014/06 /25/pestisida-kimiawi-berlebihanhama-penggerek-batang-malah- 
berkembang/. Diakses 28 Febuari 2019.

Channa, N.B., Bambaradeniya and Felix P. Amarasinghe. 2004. Biodivirsity Associated with The Rice AgroEcosystem in Asian Countries: A Brief Review. Ghana, Pakistan, South Africa, Srilanka, Thailand: IWMI.

Nutani. 2016. Cara Pengendalian Burung Pipit Pada Padi.

https://www.nutani.com/cara-pengendalianburung-pipit-pada-padi.html. $\quad$ Di akses 28 Febuari 2019.

Sallisbury FB dan Ross CW. 1995. Fisiologi Tumbuhan Jilid II. Lukman DR, Sumaryono, Penerjemah. Bandung
(ID): ITB Pr. Terjemah dari: Plant Physiology, $4^{\text {th }}$ Eddition.

Sallisbury FB dan Ross CW. 1995. Plant Physiology. California: Wadsworth Publishing Company Belmont.

Sembiring, A. S. 2013. Sistem Pakar Diagnosa Penyakit dan Hama Tanaman Padi. Medan: STMIK Budi Darma. Vol 3.

Soepardi, G. 1983. Sifat dan Ciri Tanah. Bogor: Fakultas Pertanian Institut Pertanian Bogor.

Unterstenhofer, G. 1963. The Basic Principles of Crop Protection Field Trial. Leverkusen: Repr Planzenschults, Nachrich, ten Bayer A.G. Hal 169-170. 